\title{
Analisis Persepsi Followers Instagram Akun @marioteguh Mengenai Personal Branding Mario Teguh Pasca Kasus Pengakuan Anak Kandung oleh Kiswinar
}

\author{
Deandra Shivana $^{1}$, Soraya Nurida ${ }^{2}$, dan Joe Harrianto Setiawan ${ }^{3}$ \\ ${ }^{1,2,3}$ Institut Komunikasi dan Bisnis LSPR, Jakarta, Indonesia
}

\begin{abstract}
ABSTRAK
Penelitian ini dilakukan dengan tujuan untuk mengetahui tentang analisis persepsi publik terhadap personal branding Mario Teguh yang diambil dari followers Instagram @ marioteguh setelah kasus Kiswinar yang mengaku sebagai anak kandungnya menjadi perhatian publik pada tahun 2016 lalu. Teori utama yang digunakan adalah Personal Branding Concept dan metode yang digunakan adalah metode kualitatif. Pengumpulan data dilakukan melalui wawancara whatsapp. Berdasarkan studi penelitian ini, Mario Teguh memiliki dua dari tiga elemen personal branding yaitu kejelasan dan spesialisasi tetapi gagal mendapatkan elemen konsistensi karena perbedaan antara personal branding dan kenyataan setelah kasus Kiswinar.
\end{abstract}

Kata kunci: Personal Branding, Mario Teguh, Kiswinar, Analisis, Persepsi

\section{Perception Analysis of Instagram Followers @marioteguh Account Regarding Mario Teguh's Personal Branding After the Case of Confession of Biological Children by Kiswinar}

\begin{abstract}
This research study is conducted with the objective to learn about the analysis of public's perception from Mario Teguh's personal branding thatwas taken from the Instagram followers of @marioteguh after the case of Kiswinar who claimed to be his biological son came to the public's attention on 2016. The main theory used is Personal Branding Concept and the method that's used is qualitative method. Data collective is through whatsapp interview. Based on this research study, Mario Teguh has two from three elements of personal branding which are clarity and specialization but failed to obtain the consistency element because of the difference between his personal branding and the reality after the case of Kiswinar.
\end{abstract}

Keywords: Personal Branding, Mario Teguh, Kiswinar, Analysis, Perception

\section{PENDAHULUAN}

Industri dunia hiburan di Indonesia sudah semakin pesat, dapat dilihat dari banyaknya sosok 
selebriti yang semakin banyak muncul di layar kaca atau media daring. Sosok artis selalu terkait dengan orang-orang yang populer pada bidang-bidang tertentu dan erat kaitannya dengan fisik yang mudah dikenali dan berciri khas. Artis memiliki profil menonjol di media pada kesehariannya, sehingga seseorang dapat dikatakan artis ketika seseorang tersebut mampu menempuh hasil dari karir yang sukses di bidang tertentu (Prihantoro, 2013).

Tentu setiap orang memiliki latar belakang masing-masing dalam memenuhi kebutuhannya. Terdapat juga alasan utama untuk membangun kesan pertama yang baik, sehingga orang lain mampu menilai sebagaimana yang kita inginkan dimata publik. Dalam mencapai tujuannya, para pengguna Instagram berusaha mengembangkan perilaku-perilaku yang mendukung peran sesuai yang diinginkanya (Dhara et al., 2020). Pengguna juga harus memperhitungkan setting (tempat foto), kostum (pakaian yang digunakan), penggunaan kata (caption pendukung) dan lainnya untuk meninggalkan kesan baik pada lawan interaksi (Ariani dan Trigartanti, 2016).

Personal Branding adalah proses dimana seseorang dan karirnya ditandai sebagai brand atau merek dan hal tersebut berbeda dengan tujuan dari reputasi dan impresi. Personal Branding ditujukan untuk membentuk sebuah aset dari seorang individu, termasuk pada pengetahuan yang dimiliki, kemunculan diri dan lainnya, yang dapat membantu untuk membentuk impresi yang mudah diingat dan unik (Karaduman, 2013). Personal branding adalah sebuah cara untuk memasarkan diri atau citra diri secara individu. Berdasarkan jati diri yang unik, setiap individu dapat membangun brand-nya secara solid sehingga mampu berada di kalangan yang ingin dituju. Langkah ini mengadopsi ilmu marketing dalam membangun personal brand, seperti halnya membangun brand produk, dengan cara membangun dan mengkomunikasikan personal brand secara konsisten, jelas, dan memberikan pengaruh positif terhadap orang lain (Herworld.co.id, 2014).

Menurut Chritton (2012) dalam buku Personal Branding for Dummies, personal branding adalah upaya yang berlangsung dan secara teliti untuk melihatkan kepada masyarakat luas tentang keunikan dan keaslian dari diri anda dan bukanlah versi diri anda yang tidak dapat di pertahankan. Personal Branding merupakan proses untuk membawa setiap aspek dari hidup menjadi sebaris dengan karakteristik, kekuatan, nilai dan tujuan, agar impresi yang diciptakan dapat bertahan lama. Personal Branding adalah reputasi yang didefinisikan oleh karakter. Personal Brand dapat juga dikatakan warisan hidup, karena melalui personal brand lah orang lain dapat mengingat apa yang anda lakukan, keahlian anda dan koneksi emosional yang anda miliki dengan masyarakat (Chritton, 2012).

Personal Branding adalah hal yang sudah dimiliki, dengan atau tanpa sadar dari seorang individu. Melalui personal branding, seorang individu dapat mengetahui mengenai cara untuk mendapatkan nilai lebih pada dunia kerja dan juga untuk target market yang dituju (Chritton, 2012). Mengatur reputasi, gaya, penampilan, sikap dan kemampuan adalah termasuk dalam personal branding. Ide dari personal branding adalah dengan mengasosiasikan simbol-simbol yang sesuai dengan diri seorang individu. Personal branding bukan lah suatu hal yang hanya di invest dalam satu atau dua jam, dan tidak dipikirkan lagi kedepannya. Personal branding adalah satu hal yang harus terus menerus dipelihara penuh dengan perhatian yang cukup dan 
ketelitian (Rakhmadhona, 2020).

Dengan memiliki personal brand maka dapat menambah kesempatan untuk mendapatkan word-of-mouth advertising yang memudahkan untuk membangun reputasi yang baik untuk meningkatkan karir kedepannya, sehinga berhubungan dengan stakeholders menjadi lebih mudah tanpa harus meyakinkan tentang diri seorang individu, dan terfokus lebih pada payment, servis apa saja yang akan digunakan dan melakukan proyeknya (Ernungtyas \& Irwansyah, 2019).

Personal brand dapat dibangun dengan konsistensi, perencanaan yang baik dan terpercaya. Dengan membangun personal brand, maka kepribadian adalah aset terbesar yang harus dijaga agar selalu tampak baik dimuka umum. Jika ada hal negatif yang dilakukan dan terdokumentasi, terkhusus pada jaman milennials dimana media sosial dan internet menjadi ruang public yang dilihat dan dinilai oleh masyarakat dengan akses bebas, maka personal brand yang sudah dibangun dapat rusak dan beresiko besar untuk kehilangan pekerjaan (Mustofa, 2017).

Peneliti menemukan 2 penelitan sebelumnya yang sejenis atau memiliki keterkaitan dengan penelitian yang sedang dikerjakan. Pertama, penelitian yang sebelumnya memiliki keterkatian dengan penelitian ini dikerjakan oleh Susilo Wibisono yang berjudul Kegemaran Bermain Game Online Pada Mahasiswa. Penelitian ini memiliki tujuan untuk mengungkap faktor-faktor apa saja yang menjadi pendorong para gamers melakukan permainan game online, kedua untukg mengungkap berbagai proses dan orientasi yang terjadi selama permainan game online pada kalangan mahasiswa dan yang terakhir untuk mengetahui bagaimana dinamika psikologis dari permainan game online pada para gamers yang terbaik dengan peran sosial yang harus dijalankan sebagai individu yang berada pada tahap dewasa awal dan individu yang berstatus sebagai mahasiswa. Hasil penelitian tersebut menyimpulkan bahwa kegemaran bermain game telah dimulai dari kecil. Keputusan untuk menjadi pemain game akan terwujud ketika mahasiswa tersebut mendambakan adanya kebebasan berpikir bahwa dunia maya-lah yang bisa memberikan kebebasan tersebut. Kedua, penelitian yang sebelumnya memiliki keterkatian dengan penelitian ini dikerjakan oleh Rio Ricky mahasiswa Fakultas Komunikasi dan Bisnis Universitas Telkom serta dengan Ratih Sudrajat dan Indra Pamungkas. Penelitian ini memiliki tujuan untuk mengetahui pola komunikasi kelompok virtual di dalam kelompok virtual 1-ron dan juga untuk mengetahui proses interaski yang terjadi dalam komunikasi kelompok virtual 1-ron. Dari hasil penelitian tersebut dapat disimpulkan bahwa semua anggota clan 1-ron dapat menyampaikan pesan dengan bebas tanpa perantara. Dikarenakan adanya kecocokan pada karakteristik komunikasi pada clan 1-ron serta komunikasi yang bersifat terbuka, tidak terbatas dengan tingkat jabatan anggotanya dan tidak melewati perantara untuk memberikan informasi, sehingga komunikasi terjadi sangat lancar tanpa hambatan.

Brand menurut Smith \& Zook (2011) pada buku Marketing Communications; Integrating Offline and Online With Social Media adalah merupakan hal yang dapat di lindungi, aset yang bernilai dan tidak ada wujudnya. Brand adalah sesuatu yang dilihat oleh customer atau target audience nya dari sebuah perusahaan atau sebuah produk. Merek atau brand adalah semua hal 
yang dilihat oleh customer atau stakeholder, dirasakan dan dialami mengenai sebuah produk atau servis. Brand adalah sesuatu hal yang membedakan diantara persaingan produk dan servis.

a. Kekuatan pada brand terletak saat brand membela perusahaan dari pesaing, menjaga hubungan antara customer, menaikkan penjualan, menguntungkan dan menyeimbangkan aset. Merek mengontrol manusia dan ekonomi seperti yang dikatakan oleh Winston Fletcher

b. What gives brands their power to influence - if not quite control - people's purchasing decisions and thus their power to influence - if not quite control - modern economies? (Fletcher, 2011, p.33)

c. Brand mengurangi resiko yang terlihat. Merek yang kuat adalah yang memperlihatkan garansi atau janji akan kualitas, gaya dan reputasi. Merek dibangun atas dasar kepercayaan. (Smith \& Zook, 2011).

d. Hubungan tentang merek selalu sulit karena kesalahan sedikit atau sekecil apapun dapat menjadi kehancuran, seperti contoh walaupun hanya kontaminasi atau salah penempatan kata. Customer tidak hanya berbicara balik atau memberi feedback, namun juga 'menggigit dan berteriak' saat brand tidak menepati atau merusak janji (Smith \& Zook, 2011).

Menurut Ruslan (2010), Menyebutkan bahwa terdapat beberapa peranan dari public relations yang dijabarkan sebagai berikut:

1. Communicator, yang mengartikan bahwa sebagai komunikator yang baik secara langsung atau tidak langsung, melalui media cetak/elektronik dan secara lisan, selain itu juga bertindak sebagai mediator sekaligus persuader.

2. Relationship, Kemampuan peran Public Relations membangun hubungan positif antara lembaga yang diwakilinya dengan public internal dan eksternal.

3. Back-up Management, Melaksanakan dukungan manajemen seperti promosi, pemarasan, operasional, personalia dan sebaainya untuk mencapai tujuan bersama dalam suatu kerangka tujuan pokok.

4. Good Image Maker Menciptakan Citra atau publikasi yang positif merupakan prestasi dan juga tujuan utama aktivitas public relations dalam melaksanakan manajemen kehumasan membangun citra atau nama baik suatu lembaga/organisasi/produk yang di wakilinya.

Menurut Kucharska (2017), personal branding adalah sebuah efek yang direncanakan oleh identifikasi dari sebuah merek, yang krusial untuk nilai merek yang akan diciptakan pada dunia sosial. Dikatakan juga bahwa personal branding adalah bagian dari proses self-marketing, dimana memiliki peran penting untuk menginformasikan kepada khayalak luas mengenai brand dari diri sendiri untuk kepentingan pekerjaan dan jenjang karir. Brand dari seorang individu seharusnya terfokus pada nilai seorang individu, kepercayaan pribadi dan ketertarikan pribadi (Kucharska, 2017). Personal Branding adalah identitas pribadi seseorang yang mampu menciptakan respon emosional terhadap orang lain mengenai kualitas dan nilai yang dimiliki oleh orang tersebut (Tamimy, 2017). Personal Branding adalah tentang mengendalikan bagaimana satu orang melihat satu orang lainnya sebelum mereka berinteraksi langsung satu dengan lainnya. Setiap orang sudah memiliki Personal Brand, karena semua orang sudah memiliki sebuah persepsi mengenai seseorang. Personal Branding adalah merek yang seseorang bangun tanpa sengaja dan tanpa menyadarinya (Montoya \& Vandehey, 2009). 
Personal branding bukanlah sebuah pilihan, karena setiap orang, produk, maupun perusahaan telah memiliki personal branding-nya sendiri. Hanya yang menjadi pertimbangan adalah seberapa besar kekuatan personal branding tersebut mampu terekam kuat di benak dan pikiran orang lain (Tamimy, 2017). Peneliti menggunakan teori Personal Branding karena kasus pengakuan anak kandung oleh Kiswinar pada Mario Teguh menjadi salah satu alasan yang kuat Mario Teguh tidak menjalani program motivasi pada media televise lagi, dan memiliki pengaruh besar pada personal branding dari Mario Teguh. Peneliti ingin mengetahui seberapa besar kekuatan kasus pengakuan anak kandung oleh Kiswinar pada Mario Teguh dapat mempengaruhi opini public mengenai personal branding dari Mario Teguh.

Elemen-elemen personal branding adalah sebagai berikut (Montoya \& Vandehey, 2009):

1. Clarity. Personal Branding harus memberi tahu orang lain mengenai diri sendiri dan apa yang sudah dilakukan selama ini serta apa yang akan dilakukan secara spesifik dan untuk siapa.

2. Specialization. Kunci kedua adalah seseorang harus berbeda dari pesaing atau orang lain untuk diperhatikan dan diingat oleh publik. Spesialisasi berarti mempertaruhkan "posisi" yang sangat tepat yang membedakan seseorang dengan satu orang lainnya.

3. Consistency. Orang memiliki banyak hal yang ingin mereka perhatikan. Biasanya, orang akan mulai memperhatikan dan menghargai Personal Branding seseorang ketika terdapat konsistensi dalam membangun personal branding.

Personal brand bertujuan untuk mendapatkan posisi di hati, di benak, serta pikiran khalayak, demi memperoleh perhatian dan dukungan yang dapat menginspirasi pihak lain atau khalayak. Keunikan dapat membuat khalayak mudah mengingat citra diri seseorang, dan menjadi pembeda dari orang lain (Loretta, 2015). Personal branding menghasilkan keuntungan internal maupun eksternal. Secara eksternal, seseorang bisa menciptakan sebuah identitas yang menghubungkan dengan orang lain sehingga tercipta koneksi yang diinginkan kepada orang yang ingin dijangkau. Sebagai keuntungan internalnya, personal branding berfungsi sebagai pengendali diri, yang mengarahkan seseorang ke arah yang dituju dalam semua aktivitas. Setiap tindakan yang seseorang lakukan akan memperkuat atau melemahkan personal branding nya, sehingga personal branding yang jelas akan memberikan pemahaman yang jelas tentang diri seseorang itu sendiri (Rockefeller, 2017).

Peneliti ingin mengetahui bagaimana Mario Teguh dimata publiknya setelah kasus pengakuan anak kandung oleh Kiswinar yang melanda karir dari motivator ternama seperti Mario Teguh. Pada penelitian ini, peneliti menggunakan tiga konsep yang membahas mengenai personal branding (Montoya \& Vandehey, 2009). Yang menyatakan teori 'The Brand with Three Brains', dimana maksudnya adalah personal branding yang efektif dan efisien, yaitu:

a. Specialize/Spend. Spesialisasi adalah hal penting dalam personal branding. Seseorang tidak bisa membangun personal branding yang efektif ketika tidak memiliki spesialisasi. Jika seseorang memiliki spesialisasi dalam bidang yang dia kuasai, maka orang lain akan tertarik. Berikut adalah keuntungan dari spesialisasi:

1. Diferensiasi. Orang akan tertarik ketika seseorang memiliki bidang yang dikuasai, bidang yang dipahami, dan keunikan yang membedakan dengan orang lainnya. 
2. Keahlian Menduga. Ketika seseorang mengatakan pada orang lain bahwa diri nya ahli dalam bidang tertentu, maka secara natural akan percaya. Mereka menghormati, dan bahkan membayar jika diperlukan.

3. Fokus Pada Kekuatan Diri. Spesialisasi mengharuskan seseorang untuk fokus pada bidang yang dikuasai. Maka seseorang tersebut akan lebih menikmati pekerjaannya.

b. Branding Channels. Ini adalah tahap kedua dari personal branding. Terdapat dua kategori dari branding channels, yaitu:

1. Inclusive Channel. Seseorang tidak dapat mengatur pada channel ini, dimana respon yang didapat terhitung luas dan besar.

2. Excusive Channel. Pada channel ini, seseorang dapat mengontrol siapa yang melihat pesannya. Akan tetapi jangkauan cakupannya sedikit.

\section{METODE PENELITIAN}

Penelitian ini menggunakan metode penelitian kualitatif deskriptif. Menurut Sugiyono (2009) metode penelitian kualitatif adalah metode penelitian yang digunakan pada kondisi objek yang alamiah, dimana peneliti adalah sebagai instrument kunci, teknik pengumpulan data dilakukan secara triangulasi (gabungan), analisis data bersifat induktif dan hasil penelitian kualitatif lebih menekankan makna dari pada generalisasi. Teknik pengumpulan data yang digunakan adalah wawancara mendalam dan observasi, dan peneliti menggunakan triangulasi sumber sebagai teknik pemeriksa keterpercayaan. Narasumber yang dipilih oleh peneliti untuk penelitian ini adalah figur-figur dalam esports Indonesia itu sendiri dari sisi pemain hingga event organizer.

Penelitian kualitatif merupakan pendekatan untuk mengeksplorasi dan memahami makna individu atau kelompok yang dianggap sebagai masalah sosial atau manusia. Proses penelitian melibatkan pertanyaan dan prosedur yang muncul. Peneliti membuat interpretasi tentang makna data. Laporan tertulis terakhir memiliki struktur yang fleksibel. Mereka yang terlibat dalam bentuk penyelidikan ini mendukung cara untuk melihat penelitian yang menghargai gaya induktif, fokus pada makna individu, dan pentingnya menghadapi situasi yang kompleks (Creswell, 2013).

\section{HASIL DAN PEMBAHASAN}

Mario Teguh yang bernama asli Sis Maryono Teguh lahir di Makassar pada 5 Maret 1956. Beliau meraih gelar Sarjana Pendidikan dari Institut Keguruan dan Ilmu Pendidikan (IKIP) di Malang dan mendapatkan gelar MBA Jurusan Operations Systems di Indiana University, Amerika Serikat, pada tahun 1983, yang kemudian bekerja pada perusahan perbankan multi nasional, Citibank, sebagai head of sales, hingga tahun 1986, meneruskan pekerjaannya pada BSB Bank sebagai Manager Business Development hingga tahunu 1989, lalu bekerja pada ASPAC Bank di tahun 1990 sebagai Vice President Marketing and Organization Development hingga tahun 1994, yang lalu beliau mengundurkan diri untuk mendirikan bisnisnya sendiri dalam bidang konsultan bisnis hingga saat ini (Wijaya, bio.or.id).

Sebelum Mario Teguh memiliki acara Golden Ways, beliau membawakan acara bertajuk Business Art pada stasiun TV O'Channel, yang lalu namanya semakin dikenal luas setelah 
membawakan acara Golden Ways, dengan tagline nya The Golden Ways, dan salam andalannya yakni "Salan Super". Dengan memiliki latar belakang pendidikan dan pengalaman kerjanya dalam beberapa perusahaan multi nasional, Mario Teguh membangun personal brand yang teguh, kuat, bijak, menginspirasi dan dapat merangkul semua kalangan. Personal brand tersebut juga mendapat dukungan dari penghargaan-penghargaan yang diterima oleh Mario Teguh seperti; Tokoh Perubahan 2009 oleh Republika dan rekor MURI dengan Facebook Fans terbesar di dunia pada tahun 2010. Pada saat artikel ini ditulis, Mario Teguh mendapat predikat sebagai motivator termahal di Indonesia (Wijaya, bio.or.id).

Kehidupan Mario Teguh sebagai seorang motivator dan public figure tentu saja mendapat perhatian banyak dari public. Pada tahun 1993, Mario Teguh menikah dengan Linna Teguh yang lalu dikaruniai dua anak bernama Audrey Teguh dan Marco Teguh. Mario Teguh, memiliki beberapa acara TV sendiri yang membicarakan seputar motivasi, dengan salam yang sering diucapkan saat penutupan acara, 'Salam Super.' Dalam karirnya, Mario Teguh berfokus pada emotional intelligent atau kecerdasan emosi, dan anger management. Mario Teguh juga sering memberikan nasihat atau motivasi tentang mengagungkan wanita, yang dilakukan oleh nya sendiri, sebagaimana ditulis pada akun facebook miliknya; "Kami sudah menikah lebih dari 23 tahun dan tidak sehari pun terpisah, dan memiliki satu sama lain sebagai yang satusatunya. Saya tidak menduakan ibu Linna dan menyerahkan semua uang dan harta keluarga kepadanya karena saya harus membuktikan nasihat saya tentang memuliakan wanita dan agar saya bisa berfokus melakukan yang terbaik dalam pelayanan saya kepada sesama" (Wink, biografiku.com).

Mario Teguh termasuk motivator yang aktif pada media sosial baik Instagram maupun Facebook. Akun Instagram yang dimiliki oleh Mario Teguh memiliki 3 juta pengikut dengan jumlah tautan sebanyak 13,100 dan 3 akun yang diikuti yang mana hanya anggota keluarga yang selama ini diperlihatkan yakni; Istrinya, Linna Teguh dan kedua anaknya Marco dan Audrey Teguh (instagram.com/marioteguh).

Saat ini, Mario Teguh tidak lagi memiliki program televisi dan hanya berfokus pada media sosial Facebook dan Instagram untuk tetap memotivasi para pengikutnya, serta membagikan beberapa foto keharmonisan rumah tangganya dengan istrinya, Linna Teguh. Diluar dari kegiatan media sosial, Mario Teguh tidak aktif pada acara-acara televisi (Sandi, P.E, balitribunnews.com).

Penelitian ini menemukan tiga temuan utama yaitu clarity, specialization dan consistency. Pada aspek clarity, Mario Teguh sudah menunjukkan bahwa dirinya sudah diketahui publik sebelum kasus pengakuan anak kandung oleh Kiswinar dan dikenal oleh publik sebagai seorang motivator yang inspiratif, praktis, mudah dimengerti, relatable dengan audiens nya, dan menciptakan rasa nyaman dari caranya berkomunikasi dengan audiens nya. Melalui internet research, didapatkan juga bahwa Mario Teguh, memiliki banyak pengikut pada fanbase maupun pada media sosial yang mengetahui bahwa dirinya adalah seorang motivator. Disebutkan juga oleh Rony Wijaya pada bio.or.id saat artikel itu ditulis bahwa Mario Teguh adalah motivator termahal di Indonesia. Disini menjelaskan bahwa aspek clarity sudah dimiliki 
oleh Mario Teguh, bahwa dirinya diketahui secara spesifik sebagai seorang motivator. Mario Teguh memenuhi elemen clarity pada personal branding yang mana Mario Teguh dengan berhasil memberi tahu orang lain mengenai diri nya secara spesifik, yakni seorang motivator dan apa yang beliau lakukan selama ini, sesuai dengan yang dia inginkan, sebelum adanya kasus pengakuan anak kandung oleh Kiswinar. Dibuktikan oleh Zara Farah yang mengatakan "Mario Teguh adalah sosok yang pembawaannya sangat firm, dewasa dan dapat menunjukkan bahwa beliau adalah sosok problem solver yang baik”.

Pada aspek specialization, Mario Teguh sudah menunjukkan bahwa dirinya memiliki karakteristik yang menonjol dan berbeda dari karakteristik motivator lain yang diketahui oleh audiens nya yang menjadi narasumber pada penelitian ini. Mario Teguh digambarkan dengan sosok yang dewasa, pemecah masalah yang baik, sosok kepala keluarga yang baik dan dapat dicontoh serta menyayangi keluarganya dengan sangat. Mario Teguh juga disebut menjadi motivator Indonesia dengan bayaran termahal, menurut Rony Wijaya pada bio.or.id yang dapat memberikan alasan bahwa Mario Teguh berbeda dari pesaing motivator lainnya dan Mario Teguh sudah memiliki posisi yang tepat sebagai motivator, sebelum adanya kasus pengakuan anak kandung oleh Kiswinar. Jawaban dari Ratih Purnami pun memantapkan aspek specialization yang dimiliki oleh Mario Teguh dengan jawaban: "Ya, saya mengetahui motivator lain selain Mario Teguh, namun saya tidak mengikutinya karena penyampaiannya yang berbeda dengan Mario Teguh, dimana pembawaannya terlalu teoritis dan membuat pusing. Berbeda dengan Mario Teguh yang membawakan dengan bahasa yang mudah dicerna”.

Dari jawaban-jawaban narasumber dan juga penelitian melalui internet berikut dapat ditarik kesimpulan bahwa Mario Teguh adalah sosok yang berbeda dari motivator lain, memiliki posisi yang tepat dan pembeda dari sosok motivator lainnya, yang mendukung dengan kesimpulan bahwa Mario Teguh memenuhi elemen specialization pada personal branding.

Untuk aspek consistency yang dibahas oleh Peter Montoya dan Tim Vandehey (2009, p.28), seseorang harus mempunyai konsistensi dalam membangun personal branding, sehingga orang lain dapat memperhatikan dan menghargai personal branding yang telah dibuat. Ratih Purnami dan Fhina Aulia menjawab bahwa personal branding yang disampaikan oleh Mario Teguh sebelum dan paska kasus pengakuan anak kandung oleh Kiswinar treatment nya tidak berbeda, yang mana tetap menunjukkan bahwa Mario Teguh adalah seorang motivator, menyampaikan kata-kata motivasi untuk audiens mengenai hidup dan juga sekarang membagikan keharmonisan keluarganya pada media sosial dan media online lain. Dengan tidak adanya perubahan personal branding sebelum dan paska kasus dapat dikatakan bahwa Mario Teguh secara konsisten dan terencana membangun personal brandingnya, namun konsistensi antara personal branding yang disampaikan dan realita kasus kehidupan yang berjalan mendapatkan jawaban-jawaban dari narasumber pada penelitian ini pada aspek consistency dalam personal branding Mario Teguh menjelaskan bahwa adanya kekosongan pada konsistensi tersebut dimana dalam membangun personal branding nya sehingga orang lain yang memperhatikan tidak dapat menghargai personal branding yang sudah dibuat dan menghancurkan personal branding yang ada. Walaupun yang disampaikan dan personal branding yang ada tidak 
berubah sebelum dan setelah adanya kasus pengakuan anak kandung oleh Kiswinar, namun kesimpulan dari jawaban-jawaban narasumber mengatakan bahwa mereka tidak lagi mendapatkan koneksi, kenyamanan dan percaya kepada sosok motivator Mario Teguh, setelah adanya kasus dengan Kiswinar, karena tidak mendapatkan konsistensi dari personal branding.

\section{SIMPULAN}

Berdasarkan hasil penelitian dan pembahasan serta merujuk pada masalah dan tujuan penelitian ini, maka diperoleh beberapa kesimpulan Personal Branding Mario Teguh pada persepsi publiknya (followers Instagram @marioteguh) tidak memenuhi keseluruhan personal branding, karena tidak memenuhi elemen konsistensi. Personal Branding yang ditunjukkan oleh Mario Teguh sebelum dan paska kasus pengakuan anak kandung oleh Kiswinar masih sama, sebagai seorang motivator dan membagikan keharmonisan rumah tangganya yang sekarang, walau sudah tidak memiliki program lagi pada TV, namun sekarang Mario Teguh aktif menjadi motivator melalui media sosial miliknya. Persepsi yang ada pada publiknya (publik diambil dari followers Instagram @ marioteguh) mengenai personal branding Mario Teguh paska kasus pengakuan anak kandung oleh Kiswinar adalah tidak sesuai dengan personal branding yang ditunjukkan oleh Mario Teguh. Adanya gap pada realita dan personal branding yang ditunjukkan oleh Mario Teguh paska kasus pengakuan anak kandung oleh Kiswinar menyebabkan publiknya (publik diambil dari followers Instagram @ marioteguh) merasa konten dan kata-kata motivasi dari Mario Teguh menjadi tidak relevan dan tidak membangun karena yang menyampaikan tidak dapat menyelesaikan masalah sesuai dengan yang disampaikan dengan kepada publiknya. Karena persepsi publik tidak selaras atau tidak konsisten dengan personal branding yang dibangun oleh Mario Teguh, maka publik atau audiens dari Mario Teguh tidak dapat menghargai apa yang disampaikan oleh Mario Teguh dan mulai tidak memperhatikan yang disampaikan oleh Mario Teguh. Jika personal branding dikatakan sukses, maka harus memiliki ketiga elemen yakni Clarity, Specialization dan Consistency. Jika salah satu elemen tersebut tidak dapat dipenuhi, maka personal branding dapat dikatakan tidak relevan.

\section{DAFTAR PUSTAKA}

Ariani, F., Trigartanti, W. (2016). Jurnal Seminar Penelitian Sivitas Akademika Unisba. Impression Management Seorang Selebgram Sebagai Eksistensi Diri Melalui Media Sosial Instagram. Diperoleh dari E-journal. http://karyailmiah.unisba.ac.id/index.php/humas/article/view/3160

Bangkapos. (2016). Ternyata Ini Alasan Mario Teguh Hentikan Acara Golden Ways di Kompas TV: http://bangka.tribunnews.com/2016/10/13/ternyata-ini-alasan-mario -teguh-hentikan-acara-golden-ways-di-kompas-tv

Creswell, J. W. (2013). Educational Research: Planning, Conducting, and Evaluating Quantitative and Qualitative Research Fourth Edition. Boston: Pearson. Diperoleh dari situs E-book:

http://gen.lib.rus.ec/book/index.php?md5=4DD8EC34BA58A24704851167D8481CED

Damayanti, R. [n.d]. Profil dan Biografi Mario Teguh-Motivator Indonesia: http://www.profilpedia.com/2014/05/profil-dan-biografi-mario teguh.html 
Dhara, K., Hutomo, K., Brigitta, L., \& Arzella, N. (2020). Penggunaan Instagram Sebagai Media Kampanye Politik pada Pemilihan Kepala Daerah DKI Jakarta 2017. COMMENTATE: Journal of Communication Management, 1(2), 193-207.

Ernungtyas, N. F. \& Irwansyah, I. (2019). Reading Apps Reviews and Trying Apps in Predicting the Use of Communication Apps: An Experimental Study of the Relationship Among Behavior, Attitude and Intention to Use. Jurnal Sosioteknologi, 18(1), 1-11.

Fox, Nick. (2008). Post-positivism. https://www.researchgate.net/publication/261287946_Post-positivism

Herworld.co.id. (2014). Arti Personal Branding. Diperoleh dari situs: https://www.herworld.co.id/article/2014/11/1558-Arti-Personal-Branding.

Ikhsanuddin, A. (2016). Ini Respons Mario Teguh Soal Tuntutan Minta Maaf dari Pihak Ario Kiswinar: https://news.detik.com/berita/d-3355203/ini respons-mario-teguh-soaltuntutan-minta-maaf-dari-pihak-ario kiswinar

Integrated Marketing Communications; $9^{\text {th }}$ edition. Shimp and Andrews. Diperoleh dari: https://fandango.home.xs4all.nl/Advertising\%20Promotion\%20and\%200ther\%20Aspe cts $\% 20$ of $\% 20$ Integrated $\% 20 \mathrm{Mng} \% 20 \mathrm{Communications} \% 20$ \%20Terence\%20A.\%20Shimp\%20\&\%20J.\%20Craig\%20Andrews.pdf

Karaduman, I. 2013. Procedia -Social and Behavioral Sciences Volume 99, Page 465-473; The Effect of Social Media on Personal Branading Efforts top Level Executives:https://www.sciencedirect.com/science/article/pii/S1877042813039608

Khedher, M. Personal Branding Phenomenon (2014). International Journal of Information, Business and Management, Vol. 6, No.2, 2014

Percy, L. Strategic Integrated Marketing Communications (2008). Elsevier. Inc. Canada. Kucharska, W., Confente, I. (2017). Selfie and personal branding phenomena in the context of the network economy. A literature review, Handel Wewnętrzny, 6(371), 161-169.

Loretta, D. (2015). It's Me! Superbrand Diri Untuk Jadi Beda. Jakarta: Lintas Mata. Diperoleh dari situs $E$-book: https://books.google.co.id/books?id=ja2OCgAAQBAJ\&pg=PA24\&dq=tujuan+persona 1+branding\&hl=en\&sa=X\&ved=0ahUKEwju9J78jt7XAhWLXbwKHeCAA4cQ6AEIQ

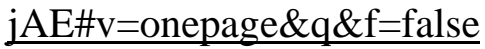

Montoya, P., \& Vandehey, T. (2008). The Brand Called You: Make Your Business Stand Out in a Crowded Marketplace. Diperoleh dari situs E-book: http://gen.lib.rus.ec/book/index.php?md5=AD8045F2F6F0D00ADE3E70F5AB7C7BB 9

Pahdepie, K. (2016). Yang Bisa Kita Pelajari dari Polemik Mario Teguh dan Ario Kiswinar: https://www.inspirasi.co/fahdpahdepie/21315_yang bisa-kita-pelajaridari-polemik-mario-teguh-dan-ario-kiswinar

Peter Gasca, (Juni 2 2016) https://medium.com/@ petergasca/a-strong-personal-brand-willenhance-your-life-no-matter-what-you-do-for-a-living-cf67e70cale8

Prihantoro, E. (2013). Jurnal Psikologi, Ekonomi, Sastra, Arsitektur, dan Teknik Sipil. Analisis Wacana Pemberitaan Selebriti Pada Media Online. Indonesia. Vol.5, No.1, p. 51-57. Diperoleh dari situs E-journal: http://ejournal.gunadarma.ac.id/index.php/pesat/article/viewFile/930/823

Prima Gumilang. (2016). Mario Teguh Minta Damai Kiswinar Menolak: https://www.cnnindonesia.com/nasional/20161127193544-12-175666/mario-teguhminta-damai-ario-kiswinar-menolak

Rakhmadhona, N. S. (2020). Upaya Meningkatkan Brand Awareness NSR Skirt Melalui 
Strategi Komunikasi Pemasaran Media Sosial. COMMENTATE: Journal of Communication Management, 1(1), 47-56.

Rizaldi, F. (2016). Mario Teguh Diberhentikan Kompas TV?: https://www.gatra.com/rubrik/hiburan/apa-siapa/219834-kuasa-hukum-kiswinarpertanyakan-pengunduran-diri-mario-teguh-dari-program-tv

Rockefeller, J. D. (2017). Personal Brand: How to Grow a Following, Boost your Career, and Skyrocket Your Income With a Powerful Personal Brand. LLC The Publisher. Diperoleh dari situs E-Book:

https://books.google.co.id/books?id=0_46DwAAQBAJ\&pg=PA2\&dq=personal+brandi ng+advantage \&hl=en\&sa $=X \& v e d=0 a h U K E w j w-$

ObLteHXAhVIqo8KHR10Cv8Q6AEIMjAC\#v=onepage \&q=personal\%20branding\%2 0advantage $\& \mathrm{f}=$ false

Sandi, E.P. (2018). Tak Pernah Muncul di TV Usai Kariernya Hancur, Begini Nasib Mario Teguh Kini. Diperoleh dari: http://bali.tribunnews.com/2018/02/09/tak-pernah-munculdi-tv-usai-kariernya-hancur-begini-nasib-mario-teguh-kini?page=all

Semiawan, C. R. (2010). Metode Penelitian Kualitatif. Jakarta: PT Gramedia Widiasarana Indonesia. Diperoleh dari situs E-book:

https://books.google.co.id/books?id=dSpAIXuGUCUC\&pg=PA7\&dq=pendekatan+kua litatif+2008\&hl=en\&sa=X\&ved=0ahUKEwj1_6ulnPTWAhUJRo8KHfc_A7AQ6AEIJ zAA\#v=snippet\&q=semiawan $\% 202010 \& \mathrm{f}=$ false

Smith \& Zook. (2011) Marketing Communications; Integrating offline and online with social media. Kogan page Ltd. Great Britain.

Srikandi, A. (2016). Berawal Tes DNA Ditolak, Mario Teguh Pernah Tak Diakui Kiswinar? Diperoleh dari; https://www.kapanlagi.com/showbiz/selebriti/niat-tes-dna-ditolakmario-teguh-pernah-tak-diakui-kiswinar-f0f456.html

Susan Chritton. Personal Branding for Dummies. Diperoleh dari: https://books.google.co.id/books?id=GF3OAwAAQBAJ\&pg=PT22\&dq=what+is+pers onal+branding $\& \mathrm{l} \mathrm{r}=\&$ source $=\mathrm{gbs}$ selected pages $\& \mathrm{cad}=3 \# \mathrm{v}=$ onepage $\& \mathrm{q}=$ what $\% 20$ is $\%$ 20personal\%20branding $\& \mathrm{f}=$ false

Sugiarto, E. (2015). Menyusun Proposal Penelitian Kualitatif: Skripsi dan Tesis. Yogyakarta: Suaka Media. Diperoleh dari situs E-book: https://books.google.co.id/books?id=jWjvDQAAQBAJ\&printsec=frontcover\&dq=sugi arto+kualitatif\&hl=en\&sa=X\&ved=0ahUKEwiEl6HQiq3XAhUJuY8KHQRNBhsQ6A EIJzAA\#v=onepage $\& \mathrm{q}=$ sugiarto $\% 20 \mathrm{kualitatif} \& \mathrm{f}=$ false

Sugiyono. (2015). Memahami Penelitian Kualitatif. Bandung: CV Alfabeta

Tamimy, M. F. (2017). Sharing-mu, Personal Branding-mu: Menampilkan Image Diri dan Karakter. Indonesia: Visimedia. Diperoleh dari situs E-book: https://books.google.co.id/books?id=6Z0sDwAAQBAJ\&pg=PA3\&dq=fungsi+citra+dir i+adalah\&hl=en\&sa $=X \& v e d=0$ ahUKEwinrbr2nqnXAhVFQY8KHYCdCbYQ6AEIQj AE\#v=onepage \&q=fungsi $\% 20$ citra $\% 20$ diri $\% 20$ adalah $\& \mathrm{f}=$ false

Tantri Setyorini, N.A, Merdeka.com, https://www.merdeka.com/ahmad-dhani/profil/ 
Vityana, I. (2015). Biografi Mario Teguh Motivator Indonesia: http://www.biografipedia.com/2015/05/biografi-mario-teguh-motivator indonesia.html

Wijaya, R. [n.d]. Biografi Mario Teguh. DIperoleh dari: http://bio.or.id/biografi-mario-teguh/

Wink. [n.d]. Biografi Mario Teguh - Motivator Terbaik Indonesia: https://www.biografiku.com/2010/10/biografi-mario-teguh-motivator terbaik.html

Wreksono, A. (2016). Dissecting Fallen Motivator's Drama: Mario Teguh vs ArioKiswinar:http://www.thejakartapost.com/life/2016/10/15/dissecting -fallenmotivators-drama-mario-teguh-vs-ario-kiswinar.html

Wulan, Suryadi, Prasetyo. (2014). Student Perception towards Personal Branding of Political Leaders on Twitter Ahead of Presidential Election 2014. A literature review Wacana, Vol. 17 no. 1.

Yunitasari \& Japarianto. (2013). Analisa faktor-faktor pembentuk personal branding dari C.Y.N. Jurnal Manajemen Pemasaran Petra. Vol. 1 No. 1 (1-8)

Gander, M. Managing your personal brand (2014). Perspectives: Policy and Practice in Higher Education, 18(3), pp 99-102. 